\section{Metamorphic Rocks, Ireland}

There appears to be confusion as to the times when metamorphic action occurred among the Irish rocks; my experience would point to the following :-

In the Carnsore district, South-East Wexford, there are metamorphic rocks for a long time supposed to be of Lower or Cambro-Silurian age; I however proved that they were upturned, contorted, metamorphosed, and denuded, prior to the overlying fossiliferous Cambro-Silurian rocks being deposited, and for the reasons given in the Geological Survey Memoir it is probable these metamorphic rocks are of Cambrian age.

In the hills north of Pomeroy, Co. Tyrone, there are metamorphic rocks, which were upturned, contorted, metamorphosed, and denuded, prior to the overlying fossiliferous "Pomeroy rocks" having been deposited. The fossils in the latter would point to their being Cambro-Silurians; consequently the metamorphic rocks are older, and for reasons given in a paper read before the Royal Irish Academy I believe they are the equiva. lents of the "great micalite series," West Galway, or the equivalents of the Arenig group of Wales. Thal is either Upper Cambrian, or Passage beds between the Cambro-Silurian and Cambrian.

In Erris, North.West Mayo, there is a tract of excessively metamorphosed rocks, supposed by Griffith to be older than the associated altered Cambro-Silurians, and this opinion is shared in by Mr. McHenry, who more recently examined them.

From the above it is evident that there was a period of intense metamorphosis prior to the Cambro-Silurian age.

The Cambrian (Arenig group?) and Cambro-Silurian of Galway and South.West Mayo must, in part, have been altered prior to the deposition of the Upper Silurians on them; while the general metamorphism of the South-East Ireland CambroSilurians, which was quite irrespective of the intrusion of the Leinster granite, was probably at about the same time. If the Comeragh Mountain rocks are Glengariff grits, i.e. Silurians, the age of the metamorphic action is evident, as in Waterford these rocks underlie those of the Comeragh Mountains. In addition to the general metamorphism in the rocks of SouthEast Ireland, there was also a local and secondary action in connection with the protrusion of certain granitic rocks.

The testimony of the West Galway and South-West Mayo rocks alone, however, would prove a period of intense metamorphic action at the close of Cambro-Silurian time.

In South-West Mayo, as proved by $\mathrm{Mr}$. Symes and myself (Maps and Memoirs of the Geol. Survey), there is a considerable area of metamorphosed Upper Silurian rocks, which prove another period of intense metamorphic action subsequent to the dawn of Upper Silurian times. The secondary metamorphism previously mentioned in South-East Ireland may also be of this age, as the granitic rocks allied with the metamorphic, in both areas, are very similar.

Thus there are records of at least three periods of intense metamorphic action, and probably there were two others sub. sequently-one in the Triassic and another in the Miocene time - to account respectively for the metamorphic rocks in the neighbourhood of the Mourne granite, Co. Down, and those associated with the granitic rock near Portrush, Co. Antrim.

Formerly, as mentioned by me in the "Geology of Ireland," the period of greatest metamorphism was considered to have been at the close of the Cambro-Silurian time; now, however, more recent research has taught us that metamorphic rocks, formerly supposed to be Cambro-Silurians, are Cambrians; so it seems possible the metamorphic action prior to CambroSilurian time may have been greater than that subsequent to it. Oroca, Ireland G. H. KiNAHAN

\section{The Number of Known Species of Hemiptera- Heteroptera}

As Mr. Yascoe, in his very "handy book of reference" for zoological classification, says of the Hemiptera-Ifeteroptera that " in round numbers there may be about 10,000 species in this sub-order," I am induced to give my census of the group.

On completing, about a year ago, MS. lists of the families which Stål unfortunately did not live to include in his " Enumeratio Hemipterorum," I was tempted to try and ascertain the total number of species that had been described. This I found to be about 7,800 (the actual number arrived at is 7,780 ). Of these, 7,445 belong to the Geocorisæ or Gymnocerata (mostly terrestrial bugs, but including four families which inhabit the surface of water), and 334 to the Hydrocorisæ or Cryptocerata (almost all aquatic species). Of the Geocorisæ I, 503 are European, 3,248 are natives of the rest of the Old World, and 2,694 are American ; of the IIydrocorisæ the corresponding numbers are 95,120 , and II9. The largest family of the Geocorise in Europe is the Capsidæ with 500 species, as against 134 and 312 in the rest of the Old World and America respectively. Amongst the Hydrocorisæ the family Corixidæ is most numerous in species, the numbers being : for Europe 72, the rest of the Old World $\mathrm{I} 7$, and America 34. But as these two families contain many inconspicuous species, and species having a strong resemblance inter se, and as Europe has been (naturally) nore thoroughly investigated than the other regions, it is likely that many extraEuropean species of these families remain yet to be discovered.

Of what may be the actual number of spscies of HemipteraHeteroptera existing it is difficult to form an estimate. It is only of late years that much attention (comparatively) has been directed to the order, and from the number of new species sent home by the few collectors who condescend to collect bugs, it is evident that very great additions to the list will in course of time be made. Even within the last twenty years the list has been more than doubled, as in A. Dohrn's catalogue, published in 1859 , only 3,627 are mentioned.

Of the sub-order Homoptera it would be rather difficult to make a census. In Dohrn's catalogue somewhere about 3,000 species are catalogued-a number not very far short of that of the Heteroptera. In the British and European lists the number of Homoptera is about two-thirds that of the Heteroptera.

Perth, October Io

F. BUChanaN White

\section{On the Classification of Rivers}

IT has often occurred to me that a convenient classification of rivers might be obtained by arranging them according to their "water-discharge." Such a classification would not only indicate the relative position of one river to another in a descending scale, but would enable a rough estimate to be borne in the memory of the amount of water any particular river may discharge.

I therefore venture to suggest the following arrangement : and have given below the names of seventeen rivers, the discharges of which I have obtained from various sources, for which I would refer the reader to NATURE, vol. xxii. p. 486 .

Discharge of Cubic Feet per second

\begin{tabular}{c|c|c|c|c}
\hline $\begin{array}{c}\text { First Rate. } \\
\text { Above } \\
2,000,000 .\end{array}$ & $\begin{array}{c}\text { Second. } \\
\text { Above } \\
\text { x,000,000. }\end{array}$ & $\begin{array}{c}\text { Third. } \\
\text { Above } \\
500,000 .\end{array}$ & $\begin{array}{c}\text { Fourth. } \\
\text { Above } \\
250,000 .\end{array}$ & $\begin{array}{c}\text { Fifth. } \\
\text { Above } \\
\text { I0o,000. }\end{array}$ \\
\hline Amazon. & Congo. & $\begin{array}{c}\text { Yang'tse. } \\
\text { Plate. } \\
\text { Mississippi. }\end{array}$ & $\begin{array}{l}\text { Danube. } \\
\text { Shat-el-Arab. }\end{array}$ & $\begin{array}{l}\text { Ganges. } \\
\text { Indus. } \\
\text { Atrato. } \\
\text { Nile. } \\
\text { Yellow River. }\end{array}$ \\
\hline \hline $\begin{array}{l}\text { Sixth. } \\
\text { Above } \\
50,000 .\end{array}$ & $\begin{array}{c}\text { Seventh. } \\
\text { Above } \\
25,000 .\end{array}$ & $\begin{array}{c}\text { Eighth. } \\
\text { Above } \\
\text { I0,000. }\end{array}$ & $\begin{array}{c}\text { Ninth. } \\
\text { Above } \\
5,000 .\end{array}$ & $\begin{array}{c}\text { Tenth. } \\
\text { Below } \\
5,000 .\end{array}$ \\
\hline $\begin{array}{l}\text { Rhone. } \\
\text { Rhine. } \\
\text { Po. }\end{array}$ & Pei-ho. & Thames. \\
\hline
\end{tabular}

Woodlane, Falmouth, October 19

H. B. GUPPY

\section{Yuccas under Cultivation}

IN Nature, vol. xxi. p. $3 \mathbf{5} 5$, in the report of the Proceedings of the Linnean Society, it is stated that "the yuccas fruit rarely under cultivation, the large white pendulous flowers being in the wild plant fertilised by a moth of the genus Pronuba." The yucca has been introduced and is very abundant in this colony, especially round Noumea. It fruits freely; in fact I rarely see a plant in which many, if not most, of the flowers do not produce seed-pods. In my own garden they seem to be fertilised by the common bee, of which $I$ have a hive, others being in the neighbourhood. If I remember rightly, Pronuba is a genus of large moths having yellow underwings. We have a species identical with, or closely resembling, an old Ceylon friend, but it is rare; still it does exist here, and may assist in the fertilisa. 